\title{
Semiotics in Haroun Hashem Rashid Lyrics Relying on the Theory of Pierce
}

\author{
Ahmad Mohammadi Nejad Pashaki ${ }^{1}$, Ahmad Reza Hidarian Shahri ${ }^{1} \&$ Kolsom Seddighi ${ }^{1}$ \\ ${ }^{1}$ Arabic Language and Literature, Ferdowsi University of Mashhad, Iran \\ Correspondence: Ahmad Reza Hidarian Shahri, Arabic Language and Literature, Ferdowsi University of \\ Mashhad, Iran. E-mail: heidaryan@um.ac.ir
}

Received: June 18, 2016

Accepted: October 17, 2016 Online Published: December 1, 2016

doi:10.5539/ijel.v6n7p31

URL: http://dx.doi.org/10.5539/ijel.v6n7p31

\begin{abstract}
Today semiotics mainly influenced by Pierce's thoughts and demarches has become an independent discipline which is used as an interdisciplinary aspect of text analysis. This approach, which uses linguistics, sociology, literature, and so forth is an efficient method of analysis. Semiotic analysis of the works in Arabic literature could lay the groundwork for a new reading of them, leading to better understanding of the texts. While introducing literary semiotics, this paper thus examines the poetry of Haroun Hashem Rashid based on the approach in question. It also appears that the encryption is related to the creator, aesthetics, text interrelationship, time, place, and the form of a poem. Given the work of Haroun Hashem Rashid, a number of roles are presented that rebuild a powerful relationship within a turbulent life, which is fluctuating between the pleasant and unpleasant symptoms. This associates likely and widespread meanings with the pure human being concepts. The results show that there is a high reliance on hypertext elements and the events of the author's life in his poetry in addition to the text elements. However, of all the most frequent indices of his poetry, time, characters, and the indications of locations can be noted.
\end{abstract}

Keywords: Peirce's semiotics, literary texts, poetry, Haroun Hashem Rashid

\section{Introduction}

Semiotics is the study of exploring signs and interpretive process, finding the occasion between the signifier and signified, and focusing on the systematic study of all the factors involved in the production and interpretation of signs and the whole process. Semiotics as an interdisciplinary study has used a variety of disciplines, including linguistics, social sciences, psychology, literary criticism, and so forth to develop and study various phenomena. Semiotics of literature is a branch of semiotics which analyses literary texts, including poetry and story. Textual analysis is seen as a form of interdisciplinarity due to the examining of implications, understanding the mechanisms shaping the discourse such as myths, metaphors, and symbols. Semiotic analysis of Arabic literature works can provide grounds for new reading and understanding the texts. The semiotics of Haroun Hashem Rashid poetry is significant, because he was the first poet who described mental and physical migration of Palestinians in his poem which include various themes of immigration and returning home. He was born in 1927 in the Olive neighborhood of Gaza City and now that we live in the mid-2016, he is turning 91. He is also the brother of a poet called Ali Hashem Rashid. "He sadly witnessed a rapist's attack in the UK and the destruction of his family home and neighbors" (Alkhazra al-Jayousi, 1997, p. 245) when he was studying at Imam-al-Shafi and Al-Falah-al-Vataniah elementary and secondary schools (Alsavafiri, 1975, p. 216). On the other hand, with the theme of a poem called "Hassan Buhairi", he was awarded the degree of PhD (Hassan, 2006, p. 436). The Palestinian poet, who spent time in exile in the early of his life, had probably little chance to find moments to be away from turmoil and turbulence and to taste the sweet home. Hashem Rashid's tragic story begins with life in exile and continued with defection, bewildered life, and finally desire to return home. He has published more than 16 collections of poetry. In 1977 he won the first prize of the poem conference of Elucose while he won the first prize of Arabic poetry of Radio London in 1988. In this paper, however, we examine the semiotics of his works to come up with the encryption of a creator, aesthetics, text interrelationship, time, place, and the form of a poem. In this way, we attempt to rebuild a powerful relationship among the turbulent world.

\section{Review of Literature}

The discussion of the semiotics of Haroun Hashem Rashid's writings is an emerging trend. Only one article 
entitled "A comparative study of women awakening" in Hafiz Ibrahim, Haroun Hashem Rashid, Kaiser Aminpoor, \& Yusufeli Myrshkak's poems has been published by Sohbat Alah Hasanvand \& Ahmad Mohammadi Nejad Baki (2012). Given that there is no article examining the semiotics of poetry Rashid Haroun Hashem, the paper is a comparative study of women in Arabic and Persian literature.

\section{Semiotics}

The discussion of semiotics has originated, developed, and expanded mainly from two sources: the ideas of Ferdinand de Saussure (1913-1857), Swiss linguist and the founder of the school of structuralism, and the writings of Charles Sanders Peirce, one of the founders of the school of pragmatism and the founder of semiotics. Although semiotics was first associated with the thoughts and ideas of Saussure and Peirce, semiotics has become an independent discipline which has developed as an interdisciplinary perspective to investigate the phenomena. In Pierce's words, semiotics is a referred framework covering any other studies. He mentioned that "never could I read something — what it is, ethics, astronomy, mathematics, sociology, history, etc. —and see it as something other than the study of semiotics" (as cited in Giro, 2001, p. 145). Nearly simultaneous with Pierce, Saussure believed that there can be a science designed to examine the life signs within the social life, and this knowledge will be part of social psychology called "semiotics". In fact, Saussure emphasizes the social functionality of signs while Peirce focuses on their logical function. However, these two aspects have a bilateral relationship with each other; therefore, "semiology and semiotic terms seem to be the same thread today. Europeans often use the former, while English and Americans apply the latter one" (ibid., p. 15). The works of Russian theorist and founder of semiotics, namely Tartu JUrij Lotman and Micheal Riffaterre, a French-born American critic, provided major models for poetry analysis. According to Lotman (1970),

Lyrics are a complex system in which each of the elements is linked together because every poem has numerous systems such as rhyme, weight, and lexical elements and the impact of that on the readers caused by the collision and conflict between the systems (as cited in Tdieh, 1999, p. 263).

Riffaterre in his book entitled "Semiotics of Poetry" distinguishes two levels for poetic texts: the level of imitation (text as a representation of reality, a chain of successive intelligence units) and semantic (text as a single conceptual unit that can be built based on interpretation). The reader understands the text in the sign level and poetry literature must pass the former level to reach its semantic one. Indeed, the reader should get through this phase to recognize the semantic network and place it under his/her control (Mc Carick, 2005, p. 331). "What is certain is that semiotics is an interdisciplinary approach; in other words, it provides a scientific and multidisciplinary background" (Dineh Scen, 2001, p. 8). Hence, we can say that the characteristics of interdisciplinary studies have been used in the analysis of semiotics texts.

\section{Semiotics in Haroun Hashem Rashid Poems}

Haroun Hashem Rashid has 14 collections of poems in a book entitled "Aamal alsheriah alkamelah" in two volumes. In this paper, the collections of Odeh Al-Ghuraba, Alhjarh Thawra, Warda ala Jabin al- Quds, and Tior al Janna have been read. With an overview of many threads of his poems, including colors, signs and colors, signs have been identified. However, finding meanings of the examples of his poems along with an analysis of their content through semiotics provides further opportunities for reading of poetries.

\subsection{Codes of the Author}

In a semiotic or semantic analysis of text, there are 4 general involved agents, including "text introducer, the recipient of the text, context involved in shaping the overall meaning, and the reading of the text" (Sassani, 2005, p. 61). Makaryk (2005) speaks of the semiotics of the author in the "Encyclopedia of Contemporary Literary Theory". He quoted Mukarovsky and mentioned that "literary work in different ways implies either directly, or in parallel the poet's life, his character, and the social environment in which he/she raised (Makaryk, 2005, p. 293). In the past, signs of the authors were in pen name which usually was brought at the end of the poem literature. Today, these symptoms are usually absent in the poems; however, his name can be seen on the back cover of his poems. Furthermore, it can be inferred the implicit evidence of the author by tracing the duplicated intellectual and stylistic elements in a poem. As for the poems of Haroun Hashem Rashid, the word "Al-Awda" (meaning return) is one of the poet's lyrical motifs, and a sign that can lead the reader to the creator of poetry. As stated by Rashid (1956),

Gaza... it is true... I'll be back... come back to God. With a heart of revenge I'll be back... yes... revenge is in advance. I'll be back in a blizzard night... Gaza I'll be back (p. 207).

The way a poet depicts a work which has a great impact on the reflection and acceptance and support of the audience. A poet in a blizzard and the night winds will not be shaken. In fact, not accustomed to displacement, 
he/she will call to return.

\subsection{Codes Associated to Aesthetics}

In the conventional sense of the relativity, Guiraud (2001) speaks of two signs of aesthetic: 1) rhetorical signs; and 2) art signs. He argues that: These aesthetic systems have dual functionality; some of them without being in the realm of logic are representative of an unknown issue, whereas others are expressing our desires. The former kind of signs includes the knowledge techniques while the latter one includes the entertaining arts in their etymological sense (pp. 93-98).

In his poems, Haroun Hashem Rashid uses techniques which are in the analysis of literary texts, aesthetic indications including the use of symbols, metaphors, hyperbole, and so on. Using these techniques, the poet uses the signs which imply their referents; these symptoms are more flexible and dynamic than the signs used in scientific languages. Words such as "Allila" (meaning night) and "Al-Fajr" (meaning sunrise in the morning) in the context of his poems are symbolic. "Allila" in many texts and poems has multiple implications such as darkness, evil, and injustice, and when is beside words such as "Alsamat" (silence), "Al-hazin" (sadness), "Alzolm" (injustice), "Al-shajoon" (grief), it means long nights, poverty, and injustice. In these works, "Al-Fajr" and its relationship with words such as rise, opening in life, and return is a symbol of openness, the release from the ordeal, and the brightness of dawn, which are reminiscent of divine illumination. In these poetries, "dawn" means passion, liberation, and return due to their vertical and horizontal axis.

\subsection{Codes of Intertextual Relations}

According to some experts, reading of a text takes place in the light of others, and there is a close relationship between texts. Intertextual term was first coined by Julia Kristeva (1969), a pioneer of post-structuralism. She influenced by Philippe Sollers believes that text was the manner in production. She gives her views on the analysis of symptoms in a book entitled "Semiotics, the study concerning the analysis signs". She believes that "a text is organized at the confluence of several texts, which includes its rereading, emphasis, displacement, and its depth (Tadie, 1999, pp. 257-261). On several occasions, Haroun Hashem Rashid considers the nature of conversation among all the texts and presents the phonetics in front of the reader of his works. One aspect is the birthplace of the poet, which evokes the memories of his homeland with its mythical image. Olive tree is a sacred tree and a symbol of Palestinian land which is also mentioned in the Holy Quran. The olive and fig on Haroun's poetry embody the good news and are the symbols of fertility and peace.

The poet has chosen them as the gospel of homeland freedom and its link with ancient history. He uses an intertextual technique to show how his text is based on the previous texts.

\subsection{Codes Related to Time and Place}

Birdwhistell (1994), one of the prominent figures in non-verbal communication in America, has introduced a linguistic model in which "time and place signs along with symptoms of motion are taken into consideration" (as cited in Giro, 2001, p. 122). Hence, "some authors in semiotic analysis of art works, including paintings, poems, and stories have also considered the signs of time and place" (Namvar Motlagh, 2003, pp. 158-159). Haroun Hashem Rashid writings suggest that his poems seem to have no explicit signs of the time and place; however, with a closer look we can examine the signs of the time and place of the other aspects. For example, according to the verbs used in the poem, it can be realized that toward what aspect of the narrative poem the poet is approaching.

Harald Weinrich, the famous German linguist (1927), distinguishes two groups of time in the article "time, place and interpreting": the first group was present, future and present perfect tense while the second group was past absolute, continuous past, and conditional past. In his view, the first group belongs to the sphere of interpretation, whereas the second group to the fabled area. By analyzing the verses of Haroun Hashem, it becomes clear that this interpretation prevails in his Divan as well.

Using present verbs and repeating them in other lines in his poems, Haroun Hashem evokes the good news of tomorrow. The place has an important role in his poetry, as he needs a place in expression of poetic narrative to give it time. This place as a sign is related to the childhood of the poet and his peers, which is a concrete and real place in itself and does not relate to hyperrealism and is not fantasy. Haroun Hashem Rashid looks into exile incredulously. As a lover he embodies Palestine as his remote love while waiting for an epic which sounds dramatic and close to him. That is why he refers to them as "El Habib" "Jamil" "Alhnun" "Latif", which are words of love, whereas there are many differences between these terms and the current face of the Palestinian awaited epic. In other words, there is a linguistic device called paradox here. Playing with words, the poet creates a contrast between them. According to Rajaei (2008), "because the term is limited while the sense is 
unlimited, the poet is forced to communicate between them." (p. 26). The two traits which are inconsistent or contradictory in the one place seem to be "mutually exclusive" (Anvari, 2002, 3, p. 1766). Sometimes the poet uses these contradictory trails to combine with his words so artfully, which "not only is admissible, but also manifesting itself beautifully". (Pakrou, 2004, p. 69)

\subsection{Narrative Codes}

Although codes of narrative are analyzed more in fictional texts, they could also be efficient in the semiotics of poetry. Many of the lyrics have a theme of the narration. Haroun Hashem Rashid's general sense of poetry is narrative. It is a narrative of a man who wants to return home; in fact, the poverty and hope that not only today's human, but also every person in each place and time wants to interact with and they cannot escape from it. His poems are narratives of a human soul which is the winner of the field in the world of pretense and deceit, and hates unreal elements. According to Roland Barthes (1956), one code is the code of practice, which deals with the chain of events while the other one is the semantic code whose goal is implicit meanings. According to Scholes (2004), Barthes's dominant interactions in his poetry are as follows:

1) Expression sufferings of life; 2) childhood memories; 3) childhood dreams; 4) description of the home's events; and 5) intellectual and moral boundaries. In his poems, he seems like an adult child, a typical brother, a typical mother, a questioning brother, and a failed prince. In his poems, the poets' position is usually at the top, and we hear the story of his poems from an adult language who sometimes tells the story of his childhood. Through the expression of this child, mature thinking, extensive experience and his deep worldview are detectable (pp. 217-218).

\section{Conclusion}

Semiotics is one of the efficient ways in the analysis of literary texts. Semiotic reading of Haroun Hashem Rashid's poems indicates that the motif "Al-Awda" is an implicit sign to understand the poet. For further beauty and influence, the poet uses signs such as symbols (cite the myth of Saladin, Mother Archetype, brother examples...), signs of hyperbolism, synonyms (evidence of victory, love of country, etc.), and allusions (historical, religious texts, and particularly the Quran). By studying the signs of conceptual relationships in his collections of poetry, we inferred that the poet has used the chains of polyphonic semantic meanings and antitheses in his poems. In the poem, we can be realize the period of the poet's life through the signs of time and place. Of the signs of their form, we can also note the internal format, music, and lyrics, which are consistent with the content of the poems. Through the examination of the intertextual signs, the relations with the religious and Quranic texts are inferred. In addition, the writings are in general narrative poems, including the codes of practice and semantics.

\section{References}

Alkhazra, A. S. (1997). Masooato Al- Adabe estini, 0.1 g. Beirut: Arabia Lelderasat.

Anwari, H. (2003). Speaking culture, $0.2 \mathrm{~g}$. Tehran: Sokhan Publishing.

Dinesen, A. M. (2001). Introduction to Semiotics (English title: Semiotics, As the German: Grundbogi wemiotik). Mozafar Qahraman (Trans.). Abadan: Porsesh Publishing.

Guiraud, P. (2001). Semiotics (Original title: Semiologie). Mohammad Nabavi (Trans.). Tehran.

Hasanvand, S. A., \& Mohammadi, N. P. A. (2012). The style of women's role in stability lyrics (Hafez Ibrahim, Haroun Hashem Rashid, Kaiser Aminpoor and Yusufeli Myrshkak). Journal Review and Comparative Literature, 6(Summer).

Makaryk, I. R. (2005). Encyclopealia of contemporary literary theory. Mehran Mohajer \& Mohammad Nabavi (Trans.). Tehran: Publication Agah.

Mohammad, H. M. (2006). Palestinian poets in modern times, i 0.1. Beirut: Eligibility for Publishing and Distribution.

Namvar, M. B. (2004). Marks the comparative poetry and painting levitation (in the works of Nizami Ganjavi and Sultan Muhammad). In F. Sojoodi (Ed.), Tehran Academy of Art (pp. 151-177).

Pakrou, F., \& Kamali, S. (Bita). Aesthetics of Persian poetry, 0.1 g. Tehran: Roozegar Publishing.

Rajayy, N. (2008). The phonetic structure of words in Arabic poetry. Essays Journal of Literature, 4(Winter), 125-139.

Rashid, H. H. (1956). Returning Alghrba', i 1. Beirut. 
Sasany, F. (2005). Subject structure analysis and structure of conscious in the context of filmic news. Tehran Academy of Art, pp. 61-81.

Sawafiri, K. (1975). Contemporary Arab literature in Palestine. Cairo: Dar Al-Maaref.

Scholes, R. E. (Bita). Introduction to structuralism in literature. Farzaneh Taheri (Trans.). Tehran, Agah Publishing.

Shafiee, K. (2005). Poet of mirrors. Tehran.

Tadie, J. E. (Bita). The twentieth-century literary criticism, translation. Niloofa Publishing.

\section{Copyrights}

Copyright for this article is retained by the author(s), with first publication rights granted to the journal.

This is an open-access article distributed under the terms and conditions of the Creative Commons Attribution license (http://creativecommons.org/licenses/by/4.0/). 